\title{
On the Playwriting of Arthur Miller
}

\author{
YuXia Fan
}

\section{Kaifeng University,Kaifeng,Henan province,475004 China}

\begin{abstract}
Arthur Miller(1951-2005),very famous American playwright, is one of the three giants together with Eugene O'Neill and Tennessee Williams. Miller has strong sense of social responsibility, considering the stage of drama to be the best way for a writer o present the society and to solve the social problems. His works have received focus on the discussion of the tragedy and American Dream. Based on two of his representative plays, Death of a Salesman and All My Sons ,this article discusses Miller's playwriting, and the ethical literary criticism will be employed to discuss Miller's moral values, trying to reveal the relationship among the individuals ,families and the society, and educating the public that the loss o morality will ce3rtainly lead to the confusion of the society.
\end{abstract}

Key words: Tragedy, Social Criticism, American family tragedy

\section{Introduction}

For the 1948-1949 theatrical season Arthur Miller's Death of a Salesman was granted the coveted Pulitzer Prize. It also received the New York Drama Critics' Circle Award, the Antoinette Perry Award, the Theatre Club Award, and the Front Page Award, as well as general critical acclaim. The dramatist so honored was then only thirty-five years old, yet this was his third play produced on Broadway. The first, The Man Who Had All the Luck(1944), closed after four performances. The second, All My Sons (1947), was widely hailed, enjoyed a good run, and garnered some awards, such as that of the Critics'
Circle. Such unusual recognition was accorded the young playwright because of his superior stage craftsmanship, his efforts to develop a new, modern type of tragedy, and his strong, serious concern with social issues affecting his fellow-countrymen.

\section{Tragedy for today:}

When the ancient Greeks or Elizabethan playwrights, such as Shakespeare, wrote tragedies, they usually selected as hero an exceptional individual occupying a high, influential position. A basically good man, with some weakness in his character or "tragic flaw", the hero eventually falls from his great height of fame, wealth, power, and respect, to the depths of misery and often to his death. As Aristotle, the ancient Greek philosopher, indicates, audiences seeing this happen experience a "catharsis," or the purifying of the spirit, as hey feel "pity "for the terrible woes of this admirable figure and "fear" because of an increased awareness of the forces in the world powerful enough to topple even the mightiest. Caught up in events of great magnitude, or so the theory goes, spectators are imaginatively liberated from all that is dull, petty, and mean in the life around them. Instead, they are stirred by the spectacle of human greatness, of Man daring to reach out beyond reasonable limits in quest of some glorious ideal. And even when he fails, as fail he must, there is still, for them, the satisfaction of having viewed nobility in action.

In sharp contrast, Miller's Death of a Salesman tells of no illustrious prince or general, 
but of an ordinary Brooklyn " drummer " (salesman), who has never been at any time rich or famous or in any way influential beyond the circle of his own family. In a sense he cannot "fall,"in the way Greek or Shakespearean heroes could, because he has never occupied a high enough position. Moreover, his objectives are ostensibly not the most exalted. He wants to be well-liked, make some money, and have his two sons also be popular and prosperous. He is largely the "common man," with rather mundane aspirations, as opposed to the traditional extraordinary or unique hero, whose dreams were breathtakingly bold.

Arthur Miller has argued, however, that if tragedy has ever had any meaning for men in general, most of whom are not kings, it must have dealt essentially with thoughts and feelings that have some universality. And the common man of today, he maintains, can be just as much the good human being with a "tragic flaw" attempting against formidable odds to transform some vision into a reality. Even if he does not want to secure a throne like Macbeth or conquer the world like Marlowe's Tamburlaine, he can at any level give himself so completely to his own personal struggle that the very intensity of his passion tends to prove Man still indomitable. Willy Loman's craving to be a well-liked, successful salesman and family man may be as ordinary as that of Joe Keller in All My Sons to leave a thriving business to young Chris. But both men, although in somewhat blundering fashion, go after their goals with fearsome, uncompromising determination. And both in a general sense go to their deaths rather than live on as acknowledged failures. Doubtless, to some extent they are psychologically warped, but they are not merely maladjusted. To some extent they are victims of a social environment instilling faulty values, but this is not the complete explanation either. For good or ill, they are men who take a stand and hold to it regardless of dire consequences. And this total commitment, heroically maintained in the face of great personal tribulation, entitles such heroes as stolid Joe Keller or distracted Willy Loman, in Miller's view, to tragic status. And since their problems are today more genuinely meaningful anyway than those of the fast disappearing aristocracy, they may point a way ,he maintains, perhaps the one possible way, in which tragic drama can elevate the spirit of the present generation.

In advancing such opinions, and carrying them out in his plays, Arthur Miller was advocating nothing completely new or revolutionary. Ibsen and O'Neill had dealt with tragic situations involving middle-class individuals; and from 1750 on through the whole Romantic period there had been much talk of the "common man." But Miller's plays were powerful, and Miller's statements strong and challenging. So his efforts on behalf of the "new" tragedy were regarded with respect and hailed as significant.

\section{Social criticism:}

Arthur Miller was, of course, not the first American playwright to view critically certain values held by our people. Eugene O'Neill's works had some comments upon the American social scene, and such writers as John Steinbeck and Clifford Odets, Robert Sherwood and Maxwell Anderson had all contributed dramas with perceptive observations about life in this country. But many of the plays produced over the years on Broadway have been superficial and trivial. Indeed, the various groups giving awards for theatrical excellence have sometimes had to skip whole seasons for want of productions worth commending. Hence, the emergence of Arthur Miller as a serious social dramatist, as well as a superior craftsman and creator of tragedies, was 
regarded with enthusiasm.

Essentially, Miller criticizes first of all the sort of family-oriented morality that causes Americans to lose sight of their responsibilities to the larger social groups of which they are also members. Joe Keller, of All My Sons, behaves admirably to his immediate family as a good, hard-working husband and father. But to save the family business, he will ship out defective plane parts that may bring woe to other American families. Willy Loman would not presumably steal from his sons, Biff and Happy. But he is tolerantly amused when they appropriate footballs or building materials that belong to others. And Willy's boss, Howard, another apparently devoted family man, is callously indifferent to the fate of an aging long-term employee. Miller shows such social irresponsibility as leading to wartime profiteering on the home front and to ruthless competition in the business world generally.

Several other dubious aspects of life here also receive critical notice in his plays. He eyes skeptically, for instance, the over-emphasis upon a sort of facile surface charm, the big smile and glad hand, at the expense of more solid virtues. $\mathrm{He}$ notes the fantastic acclaim lavished on the muscular victors of the football field, and the contrasting rejection of equally muscular trades in favor of more "respectable" white-collar jobs, however spiritually unrewarding. He speaks out against the insistence upon getting ahead and surpassing others that works against good neighborly relations. Note how readily Joe Keller sacrifices the interests of his next-door friend and partner, and how insultingly Willy speaks to Charley. In later plays, Miller especially decries the smugness and narrow-mindedness that lead to deplorable acts of intolerance.

Again, Arthur Miller was not the only writer voicing such views. Ibsen and other dramatists abroad had long before this developed a type of theatre adaptable for criticizing the values and attitudes of modern society. But in combination with his other manifest achievements, Miller's serious endeavors as an American social critic won him, from the first, encouraging recognition on the part of all who felt that the contemporary stage should show concern for the problems of contemporary life.

\section{Technical proficiency:}

Revealing early a talent for creative writing, Arthur Miller wrote several prize winning plays at the University of Michigan and afterwards sold radio scripts, all the while perfecting himself in his craft. He especially admired Henrik Ibsen, the great Norwegian master of the "well-made", tightly constructed play. And both All My Sons and Death of a Salesman have carefully planned plots, wherein skilled use is made of such typical Ibsen devices as foreshadowing, irony, and symbols. Also observed are the traditional "unities," inasmuch as each has one main story line (unity of action) that develops in and about one small area, such as the hero's house (unity of place), within a brief two-or three-day period (unity of time).

If, however, both plays evidenced command of time-tested older stage methods, Death of a Salesman also strikingly employed certain techniques associated with later experimental writers. For instance, during the 1920s, those known as Expressionists had attempted to create special effects by freely shifting action from place to place and altering the customary time sequence. In Death of a Salesman, Miller actually does keep to standard chronological order and conventional home and office locales in depicting Willy Loman's last hours from his return to his house Monday night until his suicide late Tuesday. But the famous interposed flashback scenes, representing past experiences now preying upon Willy's distracted mind, cut across more rigid plot 
lines to achieve greater fluidity. Moreover, having the set itself designed for unhampered movement and the same actors playing characters in both current scenes and flashbacks further breaks down ordinary barriers, with clever lighting and background music making transitions easy and natural.

In addition, other modern dramatists, such as Eugene O'Neill, had engaged in noteworthy efforts to deal on stage with the curious inner workings of the human mind. In The Great God Brown, for example, O'Neill had used masks to convey the difference between the characters' surface behavior and their tormented inner selves, wracked by fear and anxiety. And in his Strange Interlude, he used spoken "asides," theoretically unheard by other characters in the same scene, again to deal with hidden worries and frustrations. Another well-known playwright, August Strindberg, of Sweden, had shown in his dramas how doubts and tensions could bring about madness or lead to suicide.

In Death of a Salesman, Miller lets us know not only what Willy says to his wife, Linda, and his son, Biff, but also what memories are causing him to become mentally disturbed. He uses flashbacks, however, rather than masks or asides to reveal how inner tensions can impel a man toward self-destruction. Hence, in handling his subject, he continues the comparatively recent trend of concentrating upon psychological aspects of character.

To sum up, those evaluating Miller's work, and particularly Death of a Salesman, were much impressed with his mastery of technical skills, noting that he combined to advantage the tight structure of the "well-made" Ibsen play with the free-flowing movement of the Expressionists and the psychological analysis favored by other experimental dramatists.

\section{American family tragedy:}

Both All My Sons and Death of a Salesman deal with the business and domestic problems of middle-class American families. Both concern a father in conflict with two sons whose love and respect he ardently desires. Joe Keller wants, above all, to leave his boys a thriving business. But one, Larry, dies in the war. The other, Chris, is appalled to learn that while he was fighting overseas, his father shipped out defective plane parts. Rejected and condemned by his surviving son, Keller commits suicide. Never so prosperous as Joe Keller, Willy Loman too has great hopes for his sons, especially the elder, Biff. Willy brags to both of his boys about his being well-liked and assures them of a great future awaiting them. Biff, disillusioned upon discovering his father's deceptions, drifts from job to job, while Happy resentfully makes up for his insignificant position by sensual self-indulgence. Unable to accept their failure and his own, Willy kills himself so that he can at least leave some impressive insurance money.

Of the two, All My Sons is the more conventional in form, with Death of a Salesman achieving fluidity by the skilled use of flashbacks. In both the heroes are not highly intelligent and not given to much genuinely perceptive self-criticism. They mean well, in general, but having uncritically accepted certain values find it hard to see where they went wrong. In both instances their sons come to reject their standards and angrily point out why. This means heartbreak for the older men, with Keller eventually seeing more of the light than Willy ever does. Dramatically there is good lively conflict in these father-and-son scenes, and through the opposed points of view Miller is able to make some telling comments upon twentieth-century American life. 


\section{Conclusions:}

During the twenty years following his first Broadway production in 1944, Arthur Miller has remained in the forefront of important American playwrights. Most anthologies and histories of the drama in the country give space to his works, and productions of his plays have been given overseas. He has, of course, not escaped adverse criticism. His language has been called banal and lacking in emotional power. He has been attacked as too negative in his view of American society and especially unfair to American business. Again there have been those who have rejected his concept of tragedy as meanly bourgeois, regarding his "common man" heroes as "little" and "common "in the worst sense, and not genuinely human enough to qualify as tragic figures at all. Nor have his technical approaches been universally approved. All My Sons was found to be too rigidly constructed, After the Fall too diffusely. The Act One "Overture" to The Crucible has annoyed some commentators and the terminal "Requiem" to Death of Salesman others.

Yet the very prevalence of so much controversy over this dramatist testifies to his influential position in the American theatre. Regardless of objections posed to this or that individual aspect of his work, his reputation has remained unchallenged until recently(1964), when the critic Robert Burstein, among others, questioned Miller's worth as a dramatist. But even those who take issue with him have found admirable his continuing efforts to devise suitable new forms to express new and different themes. And among those who disagree with his literary, political, and social views are many who still find him a stimulating writer, one who at least does some thinking about vital contemporary issues. Finally, audiences for two decades have found his plays good theatre. They have wept over the death of poor, battered old Willy Loman and been awed by the plain-spoken, solid integrity of John Proctor. They have watched fascinated as deluded Eddie baits Rodolpho, they have listened with shock to the tirades of the embittered Maggie, and they have sympathized warmly with the diffidently heroic Austrian prince. Whatever else may be said, Miller commands the attention and stirs the hearts of most who come to see his dramas. And this gift is what most conclusively labels him a major playwright.

\section{Reference:}

[1]Miller, Arthur. Death of a Salesman. New York: Penguin Modern Classics, 1986.

[2] Miller, Arthur. All My Sons, in Six Great Modern Plays. New York: Dell, 1966. 